\title{
JOSEPH BINGHAM AND ASCETICISM
}

\author{
by L.W. BARNARD
}

$\mathrm{J}$

OSEPH Bingham (I668-1723) was one of the greatest patristic scholars to have adorned the English Church in its long and chequered history. Born in I 668 at Wakefield he was educated at Queen Elizabeth Grammar School, then at the height of its influence. ${ }^{1}$ On 26 May I 684 Bingham entered University College, Oxford where his zeal for persevering study found ample fulfilment in the study of the Church Fathers in their original languages. Bingham was a born student and his ability was soon recognised by his election to a fellowship of his College on I July I689. In June I69I he became a tutor and one of his first pupils was John Potter who later became archbishop of Canterbury. ${ }^{2}$ Bingham's Oxford career now seemed set fair. However the University was, at this period, agitated by the Trinitarian controversy ${ }^{3}$ and it was Bingham's fate to become embroiled in this. It cost him his fellowship and brought about his departure, at an early age, from the city and the University which he loved.

Bingham became involved in the Trinitarian controversy through being asked to preach in his turn before the university. He had apparently recently heard what he believed was an erroneous

\footnotetext{
${ }^{1}$ M.H. Peacock, History of the Free Grammar School of Queen Elizabeth at Wakefield (Wakefield I 892). University College Oxford's judgement of the School is seen in the testimony of its Master, Dr Arthur Charlett, who in 1718 presented books inscribed Bibliothecae Publicae Scholae celeberrimae de Wakefield and others in 1719 with the inscription Scholae eximiae de Wakefield. ibid p. I 29.

${ }^{2} \mathrm{~W}$. Carr, University College (London I902) is a mine of information on the College in the late-seventeenth and early-eighteenth centuries. Bingham was made deacon by the bishop of Oxford, John Hough, on 20 December I69I and priest on 12 March I $692 / 3$, both in Magdalen College chapel. MS. Oxf. dioc. papers d. 106 fols $137^{\mathrm{v}}, 144^{\mathrm{v}}$.

${ }^{3}$ From $c .1675$ the doctrine of the Trinity had become a subject of open discussion in England chiming in with the emphasis on reason which itself was a reaction against the social consequences of 'enthusiasm' among the seventeenth century sectaries. R.N. Stromberg, Religious Liberalism in Eighteenth Century England (Oxford 1954) pp. I3-I4.
} 
statement of the doctrine of the Trinity from the pulpit of St. Mary's and he thought it his duty to establish what the Fathers of the Church, rather than what the Schoolmen, had said on the subject. The sermon was given in St. Peter-le-East on 28 October I695 and contained a masterly exposition of the patristic notions of ousia, persona and substantia. The result of the sermon was, for Bingham, unexpected. He was immediately delated to the vicechancellor by J. Beuchamp, a fellow of Trinity, commonly known as 'the heretick-hunter', as having asserted doctrines false, impious and heretical, contrary and dissonant to those of the Catholic Church. The Hebdomadal Board subsequently condemned two propositions in the sermon as 'false, impious and heretical', and Dr. South, the author of a Short History of Valentinus Gentilis, denounced Bingham as a follower of Dr. Sherlock, dean of St. Paul's, who was widely held to be a tritheist. The upshot was that Bingham was forced to resign his fellowship and withdraw from the university. ${ }^{4}$

Bingham, later in his life, composed a preface to his sermon ${ }^{5}$ which throws an interesting light on his character and his method in controversy. His appeal was first and foremost to the witness of Christian antiquity which, he held, supported his view of ousia, persona and substantia. He refutes the idea that he was trying to ingratiate himself with Sherlock - in fact 'he found the Fathers wounded through Dr. Sherlock's sides' while he was condemned for saying many things which the Fathers had said before him. Yet Bingham bore no grudge against his accusers although

I could have wished for their own sakes indeed and the sake of

${ }^{4}$ The sermon is printed by R. Bingham in his edition of The Works of The Rev. Joseph Bingham M.A. vol Io (Oxford 1855 ) pp. $36 \mathrm{I}-383$ subsequently cited as Works. On Bingham's expulsion from Oxford Works vol. I pp. xviii-xix. Bingham resigned his Fellowship on 23 November I695. No trace of a formal decision against Bingham has survived in the University records apart from this note in the Life of Anthony à Wood prefixed to Athenae Oxonienses (ed Bliss p. 123): 'the meeting about Mr. Bingham is tomorrow morning at nine of the clock'. This note is dated All Souls Coll. Oxon 24 Nov. 1695 . It is possible that no formal public censure by Convocation was ever passed and that Bingham withdrew voluntarily. See however Archbishop Tenison to the Vice-Chancellor Adams 24 December I695; BL, Add. mss. 799 fol I 49 on the complaint that Bingham's sermon was contrary to the doctrines of the Catholic Church and the Church of England.

5 Works io, pp. 353-360. 


\section{Joseph Bingham and Asceticism}

the public, that they had done it a little more deliberately, and given me that month's time I desired; that I might have rendered my sermon to them, and given them a sight of my reasons, before they had censured me without hearing all that I had to say. And I could have wished also, they had told the world, that I asserted an indivisible unity of the Godhead, as well as three individual substances. ${ }^{6}$

Bingham pleads for a calm manner in Christian disputation and retained a decent respect for the characters of his accusers 'examining reasons without the least unbecoming reflections on their persons'. Such was the dignified character of this great student of Christian antiquity.

Bingham nowhere complained of the loss of his fellowship although this must have been a considerable blow to him, for it cut him off from easy access to original manuscripts of the Fathers. However the renowned Dr. Radcliffe apparently heard of his plight and presented him to the rectory of Headbourne Worthy, a mile from Winchester, and a living valued at one hundred pounds. This was to be the scene of Bingham's most celebrated literary labours.

In I702 Bingham married Dorothea, daughter of Richard Pococke, and she bore him two sons and eight daughters before he received any further preferment. However the accession of a large family and his consequent straitened financial circumstances do not seem to have depressed his spirits. Modest, gentle and unworldly Bingham pursued his studies with unwearied perseverance. In his great work on the antiquities of the Christian Church, Origines Ecclesiasticae, ${ }^{7}$ begun in 1702 , he tells us that he had to struggle with an infirm and sickly constitution and lacked many of the books he needed, although he was grateful for the use of the valuable Patristic library bequeathed to the dean and chapter of Winchester by Bishop Morley. ${ }^{8}$ A striking proof of his circumstances is provided by his copy of Pearson's Exposition of the Creed which was

${ }^{6}$ Ibid p. 358.

${ }^{7}$ Works vols $\mathrm{I}-8$. vol 9 contained his The Scholastic History of Baptism by laymen and a Dissertation on the Eighth Nicene Canon. vol to has Bingham's The French Church's Apology for the Church of England and Sermons on the Trinity, the Divinity of Christ and other matters.

${ }^{8}$ For Bingham's eloquent tribute to Morley Works I pp. xlv-xlvi and the further tribute in I p. Ixxxv. 
torn and in an imperfect state. Bingham laboriously transcribed eight missing pages in his own neat hand, although a complete copy could have been purchased for a few shillings. For some seventeen years Bingham's sole income was the endowment of the small benefice of Headbourne Worthy, and this when his domestic expenses were heaviest. However, in I7I2 Sir Jonathan Trelawney, the then bishop of Winchester, collated him to the rectory of Havant, outside Portsmouth, and then in the diocese of Winchester. ${ }^{9}$ The possession of this living, with the small sums he received from his books, removed in some degree his immediate poverty although in 1720 Bingham lost almost all the profits he had reaped from his incessant toil in the bursting of the 'South Sea Bubble'. However such was his tranquillity that it was said this heavy loss made little impression on him and not for a single day was his study interrupted. He began to prepare a second edition of the Origines and had in view a popular abridgement and supplement. ${ }^{10}$ However death, not unexpected, came on 7 August 1723 in his fifty-fifth year and he was buried in the churchyard of S. Swithun's, Headbourne Worthy, with a plain stone over his grave recording simply his name, age and year of death. Bingham had frequently expressed a dislike for pompous monuments and an inscription prepared by his first schoolmaster, Edward Clarke, was never erected in deference to his wishes. If the term asceticism refers to a strict and austere life then Bingham's has a good claim to be dignified by that designation.

\section{II}

I pass now from this short consideration of Bingham's life to the account of asceticism and monasticism in his work Origines Ecclesiasticae. The Origines is characterized by immense erudition, a

${ }^{9}$ The record of the grant of a dispensation to hold Havant in plurality with Headbourne Worthy, November 1712, is in Lambeth Palace Library.

${ }^{10}$ The Origines Ecclesiasticae was begun in 1702 and the first three volumes were published in 1708-II. Bingham was then diverted into the controversy over lay-baptism and other matters. He resumed the publication of the Origines in 1715 and the remaining volumes appeared at intervals up to 1722 . The work was translated into Latin and published by J.H. Grischovius of Halle in 1724-9. An abridgement in German was issued anonymously at Augsburg in 1788-96. 


\section{Joseph Bingham and Asceticism}

reasonableness of approach and a sureness of judgement which is largely free from a narrow controversial spirit. The late Professor A.H.M. Jones described it as 'the most useful and comprehensive work which I know on the organization and discipline of the Church'11 - a remarkable tribute to a work two-and-a-half centuries old.

Bingham's account of the ascetics in the Early Church is found in Book 7 of the Origines. He remarks that while there were always ascetics in the Church there were not always monks. Every Christian who made profession of a strict and austere life was dignified with the name of ascetic - a name which was borrowed from the ancient philosophers. So Origen refers to those who abstain from flesh in order to discipline the body; such abstinence the Apostolic Canons call aroxnous, the exercise of an ascetic life. Those, too, who spent their time largely in prayer were thought to deserve the name of ascetics - so Cyril of Jerusalem styles Anna, the prophetess, who departed not from the Temple, as ỏoxít@ı $\alpha$ $\varepsilon v ่ \lambda \alpha \beta \varepsilon \sigma \tau \alpha \dot{t} \eta$, the religious ascetic. The exercise of charity to an extraordinary degree, as when men gave up their estates to the service of God and the poor, also was termed asceticism. So Jerome calls Pierius a wonderful ascetic because he embraced voluntary poverty and lived an austere, philosophic life. Widows and virgins, according to Bingham, were also reckoned among the ascetics, as can be seen from Origen who alludes to the name when he says that the numbers of those who exercised themselves in perpetual virginity among the Christians was great in comparison to the few who did it among the Gentiles. ${ }^{12}$ So in the time of Justinian the civil law word ascetriae signified the widows and virgins of the Church. Lastly all who underwent extreme forms of hardship for the promotion of piety and religion were called ascetics. So the

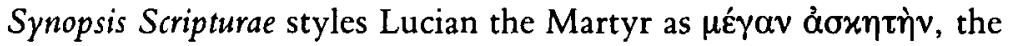
great ascetic, because of the hardships he endured in prison, being forced to lie on sharp potsherds for twelve days, with his feet and hands bound in stocks so that he could not move, and denied food. Rather than pollute himself with food sacrificed to idols he chose to die of famine, according to his Acta Martyrium. Sometimes the

${ }^{11}$ Bibliography of The Later Roman Empire (Oxford 1964).

${ }^{12}$ Works vol 2 p. $32 \mathrm{I}$. 
primitive ascetics were called by other names; so Eusebius and

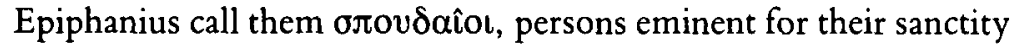
and diligence in fasting, prayer and almsgiving. Clement of

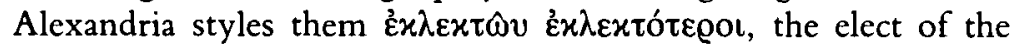
elect - while all Christians were called the elect the ascetics were the more eminent of these.

Having established the difference between ascetics and monks (a distinction which, while obvious to us, was not widely understood in his day) Bingham proceeds to discuss the rise of monasticism in some detail. ${ }^{13}$ Until c.25o there were no monks, only ascetics in the Church; from that time until the reign of Constantine monachism was largely confined to anchorites living in cells in the desert. However when Pachomius erected monasteries in Egypt other countries followed his example and so the monastic life came to full maturity in the Church.

We have no space here to summarize Bingham's account of the rise of monasticism and I will confine myself to some of the more curious items of information which he provides in the Origines. Some of this is hard to come by elsewhere. Not all monks lived up to their calling: Bingham instances the case of the Remboth, ${ }^{14}$ noted by Jerome, who were monks who lived in small groups of two or three, under no rule or government. They lived, not in the desert, but in cities and castles, turning religion to commercial gain. Whatever they sold of their own handiwork, was at a higher price than any others. They were turbulent and contentious, making even fasting a matter of strife. Everything about them was affected - loose sleeves, wide stockings, coarse clothes, often sighing, making frequent visits to virgins and always bitterly hostile to the clergy. At Feast days they indulged in riot and excess. Jerome brands them as the pests of the Church, while Cassian, who also knew about them, designates them Sarabaitae.

One of Bingham's more interesting sections is on the Stylitae or Pillarists, ${ }^{15}$ monks who lived perpetually on a pillar or column. The case of St. Simeon Stylites who lived in the mid-fifth century is well known. Even the Egyptian monks, who had sent anathematizing letters against him, came to understand and communicate with

\footnotetext{
${ }^{13}$ Ibid pp. 323-397.

14 Ibid p. 330.

15 lbid pp. $33 \mathrm{I}-333$.
} 


\section{Joseph Bingham and Asceticism}

the Syrian saint. Bingham points out that the severity of this way of life made few converts. Evagrius mentions another Simeon who lived sixty-eight years on a pillar and who is commonly called Simeon Stylites Junior. Surius, in his Catalogue of Saints, has the life of Alipius, a certain bishop of Adrianopolis, who renounced his see to live on a stone pillar for seventy years. Alipius had two choirs of virgins and one of monks attending him, with whom he sang psalms and hymns alternately day and night. Bingham clearly regards this as a legend and notes, with acerbity, that 'we scarce meet with any other of this way in ancient history'.

Bingham had a keen eye for the more unusual manifestations of monasticism. In the regions of Syria and Mesopotamia Sozomen, he notes, refers to monks called Booxoi or Grazers. These men lived in the same way as flocks and herds upon the mountains, never dwelling in houses or eating bread or flesh or drinking. They spent their time in the worship of God until feeding time when each went out with knife in hand to get food from the herbs of the field their only diet. ${ }^{16}$ Then there were the long-haired brethren, the criniti fratres known to Jerome and Augustine. ${ }^{17}$ Certain of these walked in chains, had long hair and goats' beards, wore black coats and went barefoot in winter. Such affectations in habit and dress were frowned on, and monks were to wear simple clothes and short hair as is prescribed by certain Canons of Councils.

Voluntary poverty was a sine qua non of the monastic life but not all monks could live up to this. Bingham gives the remarkable story of one of the monks of Nitria in Egypt who was punished for hoarding up a hundred shillings as his own property which he had saved out of his daily labour. At his death, when this was discovered, a council of monks had to decide what to do with the money - incredible as it may seem five thousand monks met for this consultation. Some said it should be given to the poor, others to the Church, yet others that it should be given to the monk's parents. Macarius, Pambo and Isidore and others of those called Fathers among them decreed that the money should be buried with the dead monk in his grave with the words 'Thy money perish with thee'. ${ }^{18}$

${ }^{16}$ Ibid p. 344 .

17 Ibid p. 359

${ }^{18}$ Ibid pp. $365-366$. 
Bingham largely confines his Origines to the patristic period of the Church. However his profound knowledge extended to English Church History as may be seen from his remarkable account of the Council of Becanfeld. Bingham refers to the presence of abbots or fathers at Councils of the Church where they were often allowed to sit and vote as presbyters - so at the Council of Constantinople in 448 twenty three archimandrites subscribed with thirty bishops to the condemnation of Eutyches. However England seems to have led the way in women's liberation for at the Council of Becanfeld in Kent held in A.D. 694 abbesses, as well as abbots, subscribed to the decrees and did so before both presbyters and temporal lords, according to the Saxon Chronicle. According to Bingham this is the first time that this had happened in the records of the ancient Church. ${ }^{19}$

\section{III}

It should not be imagined that Bingham was a mere compiler of curious and out-of-the-way information. He was the foremost student of Christian antiquity of his day. His appeal was always to the evidence of ancient writers, not to the opinions of later authors as to what those writers said or meant. His concern was solely to recover what the early Church believed and did and to free the study of Christian antiquity, once and for all, from the shackles of the scholastic method. Here I have only been able to provide a taste of the good things which his work, Origines Ecclesiasticae, contains by concentrating on a few extracts from one section of it. Bingham was a born student. No outward misfortune could shake his faith or turn him from his life's work. Though he received scant recognition from the Church of his day his work is a supreme expression of the spirit of Ecclesia Anglicana and to none is the proud compliment clerus Anglicanus stupor mundi more applicable. His strict, austere, persevering, scholarly life is rightly termed ascetic.

\section{University of Leeds}

${ }^{19}$ lbid pp. 373-374. 